\title{
Fenomen religii prasłowian
}

\section{Mirosław Białous}

\author{
Polska \\ kerim28@op.pl
}

Mirosław Białous, Religion of the Proto-Slavs, Elpis, 18 2016: 145-152.

\begin{abstract}
Compared to other pagan religious systems of Europe, the Slavic religion is one of the least known. There are no known Slavic myths, that is the stories of the gods. However, the written Greek and Latin sources, the Central European (Russian, Czech and Polish), as well as the material relics (eg. The statues of the deities of the four faces ) allows us to specify different forms and characteristics of the Slavic religion: the multiplicity of deities, the worship of the deified forces of nature, the worship of fire, and the original worship of the sky. The gradual process of displacing the original Slavic beliefs in the context of Christianization began in the sixth century, and finally ended with the conquest of Polabians by the Germans (13th century). However, relics of the Slavic religion survived in the private beliefs in the 15th and 16th centuries and in the folklore to this day, although the form and scale of this survival has not yet been clearly defined.

This article makes references to contemporary and earlier academic achievements in the field discussed, a reflection based on polidoxy treated as a source of polytheism and prototheism as the primary phase of polytheism. References to historical monuments and findings of historians of antiquity, for whom the Slavs were often a closed and commonly unknown societal circle, which in this manner appeared to be a threat to first the Roman Empire and then later to Western civilization.

Streszczenie: Przedstawiony artykuł ma charakter przyczynkowy, a jego zaistnienie było reakcją na pojawianie się w społeczeństwach Europy Środkowej i Wschodniej nawrotu do idei pradawnych, słowiańskich i pogańskich wierzeń. Stosunkowo ta mało rozpowszechniona dziedzina nauki, z wyjątkową trudnością poddająca się badaniom, ewokowała niejednokrotnie zaistnienie różnorodnych, często legendarnych obrazów zarówno strony mitologicznej, jak i kultycznej zagadnienia. Sytuacja taka prowadziła de facto do fascynacji przedmiotem odległym od prawdy, przedmiotem rodzącym się raczej w wyobraźni zwolenników „słowiańskich wierzeń”.

W artykule zastosowano odniesienie do współczesnych i dawniejszych osiągnięć naukowych w omawianej dziedzinie, rozważania osnuwając na analizie polidoksji, traktowanej jako źródło politeizmu oraz prototeizmu, jako fazy wyjściowej politeizmu. Nie brak odwołań do dawnych zabytków i stwierdzeń starożytnych historyków, dla których Słowianie stanowili często zamknięty i nieznany powszechnie krąg społeczny, który w ten sposób postrzegany wydawał się zagrożeniem zrazu dla Imperium Romanum, a później dla cywilizacji zachodniego świata...
\end{abstract}

Keywords: religious worship, heathen, tribes, antiquity

Słowa kluczowe: kult religijny, poganie, plemiona, starożytność.

Niniejsza propozycja tematyczna odwołuje się do bardzo szerokiej podstawy semantycznej wybranego tematu. Religia Słowian, ograniczona nawet do najbardziej skrótowo potraktowanego wymiaru to przecież system wyznań ludów zajmujących niemal 1/3 Europy, ludów ze względu na miejsce swego zamieszkania zróżnicowanych, przez kilkanaście wieków budujących swój system mentalny i zręby własnej, charakterystycznej dla siebie cywilizacji.

$\mathrm{Z}$ drugiej wszelako strony, jak utrzymuje A. Szyjewski ${ }^{1}$, nieznana etnogeneza Słowian nie pozwala jednoznacznie określić stopnia tego zróżnicowania. Współczesna nauka nie każe w nich już widzieć przybyszów z Dalekiego Wschodu, ex - koczowników stepowej Azji, sytuując ich kolebkę w rejonie bardziej swojskim: dorzeczu Prypeci czy północnych pograniczach Ukrainy i Białorusi². Nigdy nie przekroczyli Bałtyku, ale przebyli Odrę i dotarli do Renu, stanowiącego limes, granicę rzymską. Odnaleźć ich można na Bałkanach, a nawet w Wenecji... To jednak nie ułatwia analizy wierzeń...

\footnotetext{
Por. A. Szyjewski, Religia Stowian, Kraków 2003, s. 5.

Tamże,
}

Analiza przeprowadzona ex post bliższa będzie jednak ich ideowemu zjednoczeniu, aniżeli zróżnicowaniu. Na potwierdzenie przytoczmy Geografa bawarskiego (IX wiek): „[Słowianie] nigdy (wyróżnienie M. B.) nie zatracili poczucia jedności”3. Nawet podział językowy wykazuje znaczny stopień pokrewieństwa, podobny do tego, jaki występuje między narodami sąsiadującymi z sobą ${ }^{4}$. Na mocy jedności indoeuropejskiej Słowianie wykazują kulturowe związki z Bałtami, lecz kojarzenie ich z ludami irańskimi wydaje się dziś znacznym nadużyciem naukowym.

A zatem zróżnicowanie wydaje się pozorne, pozorne tym bardziej, im mniej są znane szczegóły fenomenu wierzeń. Fenomen ten odnosił się niemal do wszystkich aspektów życia, gdyż Słowianin był otwarty na religię w każdej dziedzinie swej egzystencji. Był to jednocześnie fenomen ściśle zamknięty między dwoma zasadniczymi symptomami realizacji: wierzeniami, dalekimi wszakże od śródziem-

\footnotetext{
3 Przytaczam za A. Szyjewskim, dz. cyt., s. 6.

4 Serb doskonale zrozumie Białorusina, a Rosjanin Serba. Zachodzi zatem podobna relacja jak między Norwegiem, Duńczykiem i Szwedem, którzy też mogą się porozumieć bez trudu, mówiąc każdy w swoim własnym języku.
} 
nomorskiego modelu mitologicznego i egzystencjalnym odniesieniem.

Choć znaczną siłą ludów słowiańskich był system wierzeń właśnie, nie zachował się żaden spójny przekaz go opisujący. Wprawdzie chrystianizacja Słowian trwała kilkaset lat, a do jej celów przygotowywano misjonarzy czy wręcz całe konwenty i biskupstwa, nie przyniosło to jednak rezultatu w postaci szerszej charakterystyki zwalczanego kultu. Nie zachował się odpowiednik Eddy służącej dziś do rekonstrukcji religii Germanów, a tym bardziej rodzime źródła pogańskie podobne do skandynawskich sag. W efekcie religię Słowian i ich mitologię rekonstruować można jedynie w oparciu o lakoniczne wzmianki w obcych źródłach kronikarskich lub późniejszych o przynajmniej kilkadziesiąt lat od momentu chrystianizacji źródłach rodzimych.

Fenomen religijny oferujący jednak swoisty i dla siebie charakterystyczny system przyporządkowań zmusza badacza do sięgnięcia w stronę wykraczającą niejako poza semantykę źródeł, poza klasyczne metody badawcze. Do najlepszych wyników dochodzą ci, którzy przenikając struktury plemienne zdobywają zaufanie i sami stopniowo przechwytują sposób myślenia religijnego swoich „gospodarzy". Chodzi wszak o najbardziej intymną sferę działań i przeżyć człowieka, do których to przeżyć i działań w naszym przypadku dostęp (z powodu braku źródeł) jest utrudniony.

Pomijając nawet kwestie chronologiczne, omawiane wierzenia nazwać można „religią bez źródeł” Nie można choćby jednoznacznie przydzielić określonego panteonu danym plemionom czy plemieniu (mimo świadomości mnogich bóstw lokalnych), nie można niekiedy jednoznacznie ustalić nawet boskich imion. Warto zatem fenomen ten potraktować holistycznie, koncentrując się na fenomenologicznej ejdetyzacji, na wyznaczeniu istotnych zrębów ideowo - obyczajowych stanowiących lokalne wyróżniki fenomenologiczne.

$\mathrm{W}$ tej sytuacji postanowiłem ograniczyć terytorialne oddziaływanie fenomenu do ziem środkowoeuropejskich ${ }^{5}$, za terminus ad quem chronologii ustalając czas bezpośrednio wprowadzający do działań chrystianizacyjnych na tych terenach (czyli do wieku IX), celem artykułu czyniąc uprzystępnienie bardzo interesujących zagadnień w nowym sposobie ich ujęcia.

Trudność potęguje wszakże fakt, iż fenomen słowiańskich wierzeń nie stanowi epoki skończonej, nie należy tylko do temps passé. Jego oddziaływania po dziś dzień daje się zauważyć w swoistych „pogańskich” retours. W europejskiej cywilizacji wciąż znajduje on właściwe sobie miejsce, a w czasach globalizacji i kontekście wspólnej, zjednoczonej Europy stanowi swoistą jakość, której autentyczności i sposobu oddziaływań pominąć nie sposób.

Zwłaszcza że dane odnoszące się do pierwotnej religii słowiańskiej odnaleziono pośród informacji na temat Rusi, ziem połabskich i Pomorza, aczkolwiek są to niejako informacje wtórne, w porządku chronologicznym odległe o kilka wieków i wywodzące się ze środowiska chrześcijańskiego, z natury rzeczy krytycznie nastawionego na wszystkie przedchrześcijańskie przejawy religijności. Por. K. Strzelczyk, Słowianie, Encyklopedia Katolicka, 18, 398, Lublin 2013.
W przeszłości jednak właśnie aspekt obyczajowy okazał się czynnikiem najbardziej wpływowym na zaistnienie $\mathrm{w}$ powszechnej świadomości dziewiętnastowiecznych zwłaszcza odbiorców obrazu wierzeń słowiańskich jako eskalacji dzikości, naturalizmu, by nie rzec wyuzdania i ukierunkowania na orgiastyczność 6 . Z kolei dla historyków ze „szkoły” Joachima Lelewela (1786 - 1861) właśnie prasłowiańska przeszłość Polski jawi się jako sui generis odpowiednik horacjańskiego wieku złotego, gdzie sielskość i sprawiedliwość dominowała nad wojowniczością i ekspansją ${ }^{7}$, ziemia sponte sua fructum generavit...

Niezależnie od koncepcji badawczej, fenomenologiczne ujęcie religijności prasłowiańskiej pozwala na przybliżenie faktu realizacji wrodzonej postawy religijnej człowieka (homo religiosus) $^{8} \mathrm{w}$ aspekcie jego dokonań jako uczestnika grupy religijnej, niezbędnej dla realizacji innych celów wspólnotowych. W rozumieniu zaś Słowian podstawą prawdziwości religii była jej „grupowośćc już to w wymiarze kształtowania systemu wierzeń, już to $\mathrm{w}$ fazie realizacji kultycznej.

Bo wspólnota w okresie „baśni” to egzystencjalna podstawa bytowania człowieka. Dzięki niej możliwe się staje doświadczenie antropologiczne: Homo ens ut ens, człowiek - byt jako taki.

Wspomniany wyżej brak źródeł nie neguje istnienia kilkunastu istotnych, acz porozrzucanych $\mathrm{w}$ różnych dziełach, wzmianek. Zaliczyć do nich możemy np. ruską Powieść doroczna, gdzie znajdziemy kilka opisów działań kultycznych; niemiecka Kronika Thietmara przyniesie nam opis świątyni połabskiej, a Kronika Czechów Kosmasa dość zagmatwany opis wróżb, który może wskazywać na istnienie grupy zajmujących się magią kobiet'.

Są to jednak teksty późniejsze, nie pozbawione chrześcijańskiej perspektywy prezentacji, perspektywy mocno już utwierdzonej w świadomości wyznawców. W tej sytuacji szczególne znaczenie zyskuje również reprezentująca chrześcijański punkt widzenia Historia Wojen Prokopiusza z Cezarei ${ }^{10}$, pochodząca jednak z ok. 550 roku, czyli w cza-

\footnotetext{
Doskonałym przykładem takiego podejścia jest balet Święto wiosny Igora Strawińskiego.

Taki pogląd na słowiańską przeszłość naszego kraju propagował Joachim Lelewel, a znalazła ona swe odbicie w Starej baśni J. I. Kraszewskiego. Bardzo znamienny cytat historyka: „Powiedziałem nieraz i powtarzali inni, że od wprowadzenia chrześcijaństwa do Polski, przez postęp cywilizacji zachodniej, lud utracił swą pierwotną wolność, ciągle czuł uszczerbek swobód" (za Marią Janion, Niesamowita Słowiańszczyzna, Kraków 2007, s. 96).Szczególną jakość chronologiczną tego czasu określał pisarz J. I. Kraszewski. Dla niego czas prasłowiański to okres niehistoryczny, swoisty odpowiednik starożytnej legendy, jakości mitologicznej, czyli rekapitulującej rzeczywistość „baśni”.

8 Określenie wielkiego fenomenologa religii, Mircea Eliade.

9 Por. Słowianie, Wikipedia [strona polska], (dostęp 10. XII. 2013).

10 Prokopiusz z Cezarei (490 - ok. 561) - najsłynniejszy historyk bizantyjski. W swojej twórczości nawiązywał do klasycznej historiografii Herodota, Tukidydesa. Prócz Historii wojen (w ośmiu księgach) jest też autorem Wojny sekretnej. Najbardziej znanym polskim tłumaczem jego dzieł jest A. Konarek.
} 
sie gdy Bizancjum było atakowane słowiańskimi najazdami. Znajdujemy tam bowiem bardzo istotne wzmianki na temat charakteru i jakości wierzeń, do których poniżej powrócimy. Dość dużo wiemy też o religii i religijności Słowian połabskich ${ }^{11}$.

Jednocześnie pierwsi polscy kronikarze średniowieczni (Gall Anonim czy bł. Wincenty Kadłubek) wierzeniom prasłowiańskim nie poświęcają ani jednego zdania swej narracji, ignorując je do tego stopnia, iż nawet nie thumaczą ich jako powodów reakcji pogańskiej w latach trzydziestych wieku XI. Na ten temat wypowiedział się dopiero ks. Jan Długosz, jednakże są to informacje niezbyt ścisłe, stanowiące raczej efekt wyobrażeń sytuacji religijnej słowiańskich pogan po pięciu wiekach trwałości polskiego chrześcijaństwa ${ }^{12}$.

Z uwagi na tak jednoznaczną „sytuację badawczą" nie można zrekonstruować słowiańskiego panteonu; badacz musi więc wnioskować na podstawie przesłanek, spotykając się nawet $\mathrm{z}$ ideowymi problemami.

Jednym $\mathrm{z}$ nich jest interpretacja chrześcijańska (interpretatio Christiana), ewokująca negatywny obraz pogaństwa. Nie chodziło w nim tylko, jak chcieliby świeccy badacze, o zwalczanie tego fenomenu, czy stosowanie świadomych i różnorodnych deformacji, (jak postrzega ją wspomniany już J. Gąssowski) ${ }^{13}$. lecz właśnie o wyjaśnienie, iż dopiero w chrześcijaństwie człowiek doświadczyć może pełni wolności swej egzystencji.

Z drugiej jednak strony słowiańscy poganie, zwłaszcza na Połabiu, mieli do czynienia z zachodnim modelem chrześcijaństwa, który zapewne musiał wpływać na jakość instytucjonalnego aspektu rozwoju ich wierzeń. Jakość wpływów innych wyznań czy prądów religijno - filozoficznych (kulty irańskie, manicheizm i inne) też nie jest tu bez znaczenia, nie pozwala bowiem na jednoznaczne dookreślenie ewolucyjnej linii rozwoju (a taka zapewne istniała) i „dualistyczne” zróżnicowanie słowiańskiego proprium w kontekście chrześcijańskich wpływów.

Koncentrując się na fenomenologiczno - ontologicznym ujęciu religijności Słowian możemy jednak wykazać istniejącą tam istotną dla wszystkich religii dwupodziałowość: sacrum i profanum, świętość i świeckość, pojmowaną jednak amitologicznie. $\mathrm{Z}$ całkowitym przekonaniem potwierdza to. S. Urbańczyk: „Nic nie przemawia za tym, aby u Słowian istniały mity, to jest opowieści o bogach. /.../ Są tylko słabe ich zaczątki, jak wzmianka o nocnych wyprawach Świętowita lub nie całkiem pewna opowieść o Dadźbogu - słońcu jako synu Swaroga"14. Nie oznacza to jednak, by te "zaczątki" nie ewokowały określonego milieu ideowego, nie budowały określonej postawy względem nierozpoznanych bóstw. A była ich mnogość.

Wtedy łatwiejsza zda się odpowiedź na pytanie, dlaczego poszczególne bóstwa chtoniczne czy niebiańskie nie

\footnotetext{
Religioznawstwo Polski Ludowej reprezentowane choćby przez J. Gąssowskiego uważało je za najlepiej i najbardziej szczegółowo zbadane. 12 Por. Słowianie...

13 W artykule Kult religijny [Słowian] [w:] Mały Słownik kultury dawnych Słowian, Warszawa 1972, s. 574.

14 S. Urbańczyk, Dawni Słowianie, wiara i kult, Wrocław 1991, s. 126.
}

mają jednoznacznego charakteru osobowego, co potwierdza swoiście zniekształcona forma twarzy (cztery oblicza, koniunkcja symbolu z naturalizmem itp.), dominacja „żywego" drewna niż "martwego" kamienia jako materiału do wykonywania "neo - totemów”15 itp. Także „niskiego" progu estetycznego tych przedstawień nie należy chyba zrzucać na barki niewykształconego twórcy, głębszych doszukując się przyczyn ${ }^{16}$.

$\mathrm{Za}$ jedną z nich, jak się wydaje, uznać można mnogość bóstw w postaci duchowej, Geister ${ }^{17}$, faktycznie niedookreślonych istot nie mających jednak nic wspólnego choćby z judaistyczną angelologią czy mitologią śródziemnomorską. Jedne $\mathrm{z}$ nich są duchami ziemi, zamieszkującymi wszystkie cztery jej żywioły: glebę, wodę, powietrze i ogień, one też stanowią podstawę modlitewnych odniesień słowiańskich. Nie należy też utożsamiać ich z tymi żywiołami; stanowiąc rzeczywistość sui generis autonomiczną traktują je jako swe własne milieu. Nie jest też ważne ich miano - wszak jest ich mnogość. Warto jedynie wskazać na najbardziej popularne: Meluzynę, ducha powietrza, który zwiastuje katastrofy i nieszczęścia, smoki spotykane w płynących wodach ${ }^{18}$ czy stwory i wilkołaki, o które nietrudno w lasach ${ }^{19}$.

Występowały też demony, odpowiedzialne za wegetację (sic). Zamieszkiwały one pola i odlegle połacie leśne. Ich niewidzialność i niemożliwość odkrycia tłumaczono przyzwyczajeniem do takiej a nie innej kategorii bytu. Ponadto duchy te wiązały się z określonymi porami dnia (np. „dama południa" - Mittagsfrau), a zawsze wpływały na bieg losów ziemi i człowieka ${ }^{20}$.

Nie brakowało też bóstw domowych, którym w formie folklorystycznej oddaje się w niektórych rejonach cześć nawet po dzień dzisiejszy. Chroniły one poszczególne gospodarstwa, zapewniając opiekę i pomyślność zarówno ludziom, jak i zwierzętom.

One to zapewne kazały dostrzegać też sacrum w formacjach przyrodniczych: święte góry (np. Sobótka na Śląsku), groty czy lasy uświęcały się bowiem ich obecnością.

Można tedy uznać, iż religia pierwotna Prasłowian jest kultem ubóstwionych sił przyrody $\mathrm{z}$ dostrzeganymi w nim przeżytkami totemizmu, rozwijającym się na gruncie znaczenia starszego animizmu i magii. „Patriarchalne rody rolników i hodowców bydła zależne są $\mathrm{w}$ swym bycie zarówno od rozwoju sił wytwórczych, jak i od warunków klimatycznych i atmosferycznych"21.

Ten nieco skomplikowany świat odznaczał się jednak znaczną hierarchizacją. Demony podlegały wyższym od siebie duchom, te zaś jeszcze wyższym, acz mniej licznym...

\footnotetext{
Określenie moje, M. B.

16 Hipoteza autorska

17 Szerzej na ten temat Die slavische Mithologie, Wikipedia [strona niemiecka] (dostęp 13. XII. 2013).

18 Czy nie można tu jednak zauważyć pewnej analogii z biblijnym Lewiatanem, aczkolwiek on zamieszkiwał raczej olbrzymie połacie oceanicznych wód, był jednak podobnie jak bóstwa słowiańskie raz wesoły, raz groźny

19 Die slavische..

20 Tamże.

21 Tamże
} 
Czy więc niesłuszna będzie koncepcja, iż na szczycie hierarchii znajdował się jeden bóg ${ }^{22}$ ? Czy nieuprawomocnione też będzie pytanie odnośnie do istnienia choćby namiastki monoteistycznej w tych wierzeniach? Politeizm słowiański choćby ze względu na jakość egzystencjalną wyznawców można uznać jedynie za system teologiczny, odzwierciedlający złożoność świata wyrażającą się w henoteizmie ${ }^{23}$ czy panenteizmie ${ }^{24}$.

Źródeł obu tendencji rozwojowych można się dopatrzyć w abstrakcyjnym podejściu do różnych obserwowanych przez Słowianina konkretów otoczenia. Abstrakcja ta przebiegała poprzez personifikacje sił przyrodniczych, stanowiących przyczynę zjawisk, animizację tychże, a nawet określanie wpływu dusz zmarłych na jakość kształtowania się rozwoju przyrody ${ }^{25}$. Druga, przeciwstawna jej tendencja, biorąca pod uwagę trudności abstrakcyjne Prasłowianina dostrzegała $\mathrm{w}$ henoteizmie przejaw pierwotnej postawy mentalnej ${ }^{26}$. A zatem na szczycie hierarchii świętości słowiańskich stał jeden bóg. A był nim, jak sugerują badania, najpewniej Perun. „Perun jest mnogi” twierdzili kronikarze z Thietmarem na czele, nie każąc jednak dostrzegać w innych bóstwach jego hipostazy.

Perun bowiem jawi się jako bóg najbardziej władny. Będąc bogiem burzy, grzmotów i błyskawic był tez uznawany za stróża prawa i naturalnego porządku. Nic zatem dziwnego, jak podaje Powieść lat minionych, iż on właśnie stawał się gwarantem uczciwości umów podpisywanych przez starożytnych Wschodnich Słowian ${ }^{27}$.

Podobne ujęcie potwierdza również, aczkolwiek skąpy, materiał źródłowy, który proweniencyjnie dzieli około 600 lat. Pierwszy z nich pochodzi spod pióra wspomnianego już Prokopiusza z Cezarei. Około 550 roku pisze on:

„Słowianie jednego tylko mają boga, władcę piorunów, pana wszystkiego $\mathrm{i}$ jemu tylko składają $\mathrm{w}$ ofierze woły $\mathrm{i}$ inne zwierzęta; w przeznaczenie nie wierzą i nie przypisują mu żadnej władzy nad ludźmi”28.

Odległy odeń o sześć wieków Helmold ${ }^{29}$ tak potwierdza ten henoteistyczny wymiar wierzeń słowiańskich:

\footnotetext{
2 Problem ten dość szczegółowo, acz na kilku jeno stronach porusza S. Urbańczyk (Religia pogańskich Słowian, Kraków 1947, s. 13 - 18).

23 Zagadnienie henoteizmu rozważał i termin ten wprowadził do refleksji naukowej Friedrich Max Müller, jeden z twórców zachodnioeuropejskiej indologii i religioznawstwa porównawczego, autor monumentalnego przekładu Świętych Ksiąg Wschodu (w pięćdziesięciu tomach). Wg jego

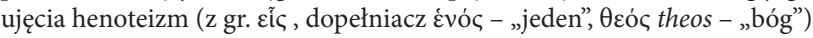
to forma przejściowa pomiędzy politeizmem a monoteizmem, w której uznaje się wielu bogów przy jednoczesnym wywyższeniu jednego bóstwa (w tym przypadku Swarożyca bądź Światowida). Pomniejsze bóstwa to formy hipostatyczne bóstwa najwyższego, nie stanowiącej z nim jednak jedności.

24 Panenteizm zakłada istnienie naczelnego boga pomiędzy innymi mnogimi bogami.

25 Por. S. Urbańczyk, dz. cyt., s. 13.

26 Tamże, s. 14

27 Por. W. Dziura, Perun, Encyklopedia Katolicka 15, 368.

28 Cytuję za Urbańczyk S., art. cyt., s. 14.

29 Helmold (1125 - 1177) historyk saski, mnich (benedyktyński), proboszcz z Bozowa w Wagrii (obecnie Bosau). Jego świadectwo jest o tyle cenne, iż obserwacje Słowian (połabskich) poczynił z autopsji, towarzysząc chrystianizacyjnym wyprawom cesarskim na Pomorzu Zachodnim. Przytoczone cytaty pochodzą z jego Chronica Slavorum, Kroniki słowiańskiej, bezcennego źródła informacji zwłaszcza na temat wierzeń współcze-
}

„Pomiędzy różnymi bóstwami, którym oddają pola i lasy, którym przypisują smutki i radości, wierzą, że jest jeden bóg na niebie, innym rozkazujący; on się o niebiańskie tylko troszczy sprawy, tamci zaś pełniący określone obowiązki od niego pochodzą; o tyle zaś każdy z nich potężniejszy, im bardziej z nim spokrewniony" ${ }^{\prime 30}$.

A zatem nie hipostaza, a pokrewieństwo.

Żadne z przytoczonych źródeł nie odnosi się jednak do istoty tego nadrzędnego boga. Stosując metody analizy porównawczej możemy jednak dojść do wniosku, iż chodzi tu o boga jasnego nieba, ojca świata. Do jego atrybutów należy zwłaszcza władza nad piorunami ${ }^{31}$.

Kult tak pojmowanego boga bywał zbieżny z kultem słońca. K. Moszyński ${ }^{32}$ widzi jednak w słowiańskim wymiarze tego kultu drogę do akceptacji systemu chrześcijańskiego, ułatwiającego recepcję jednego Boga Ojca.

Taka sytuacja ewokowała zatem zasadniczą postawę wyznawców, która charakteryzowała się magią, najbardziej prymitywnym, acz preferowanym odniesieniem do własnych, ludzkich możliwości wspartych mocami nadprzyrodzonymi. W celu augmentacji tej postawy organizowano bardzo szumne obrzędy pogańskie, a raczej atrakcyjne ich akcesoria wykorzystywane w życiu towarzyskim. Uczty, zabawy, przyozdabianie twarzy maszkarami powtarzano z określoną częstotliwością, zgodnie z duchowymi wyobrażeniami. Czy mamy tu do czynienia z odpowiednikiem starorzymskich libacji (ofiar płynnych) i towarzyszących im orgiastycznych niekiedy uczt, czy może chodzi o podkreślenie witalności i płodności? Jak sugeruje klasyk zagadnienia, J. Łowmiański, wskazane przejawy „kultyczne” zostały odziedziczone od ludności praeuropejskiej (Neurów i Wenetów), z jaką wypadło Słowianom zamieszkać33.

Warto zauważyć, iż ten kult jednego boga łatwo mieszał się z kultem ognia, gdyż niektórzy, bardziej „prowincjonalni” Słowianie uważali Słońce za „ogień na niebie” ${ }^{\text {"34 }}$ Potwierdza to również Helmold: „Popełniają Słowianie dziwny błąd, albowiem na biesiadach i przy piciu puszczają w koło czaszę, nad którą wypowiadają nie powiem, słowa zaklęcia, lecz nawet przekleństwa, wzywając imion bogów dobra i zła. Wierza oni, iż dobra dola zależy od duchów (bogów) dobrych, zła zaś od złych"35.

To samo da się orzec o prototeizmie, czyli pierwotnej czci dla nieba, które jako przedmiot kultu obdarzono nie dość precyzyjnym mianem Swaroga.

Ogólne tendencje badawcze możemy więc zamknąć w dwu kategoriach: polidoksji i prototeizmu. Polidoksja uchodzi za najbardziej pierwotną kategorię, stanowiąc etap wyjściowy do rozwoju politeizmu. Winniśmy jednak, jak sądzę, być ostrożni w stawianiu w jednym szeregu przyczy-

snej Meklemburgii.

30 Chronica Slavorum I, 84

31 Wniosek taki płynie z analizy z wierzeniami ludów bałtyckich, z których obecnie odnotować możemy jedynie Litwinów i Łotyszy.

32 Kultura ludowa Słowian, Kraków 1934, t. I, s. 437 - 454.

33 Por. tamże, s. 399.

34 Por. Moszyński, dz. cyt. I, s. 494 - 596.

35 Por. S. Urbańczyk, art., cyt., s. 18. Ten fragment stał się podstawa dyskusji na temat dualizmu, co ewokowało ustalenie odniesień do religii irańskich. 
nowo - skutkowym polidoksji i politeizmu z uwagi na stopień antropomorfizacji (czy raczej antropomorfizowania) ${ }^{36}$ przedmiotów wierzeń. O ile w mitologiach greckiego okresu klasycznego greckiego (V wiek przed Chrystusem) mamy do czynienia faktycznie $\mathrm{z}$ historią (nie zawsze uczciwych i godnych naśladowania) ludzi, o tyle polidoksja wskazując na różnorodne sposoby oddawania chwały przede wszystkim bytom nieosobowym, aczkolwiek struktura tych wierzeń wydaje się, jak na etap „wyjściowy” bardzo skomplikowana.

$\mathrm{Ku}$ odczytywaniu wierzeń prasłowiańskich przez pryzmat polidoksji ukierunkowują nas źródła (ruskie, czeskie i polskie), które ukazują te wierzenia w kontekście braku ich akceptacji przez osoby reprezentujące chrześcijań$s w^{37}$. A przecież nie wolno nam zapominać, iż ta niepoznana do końca religia słowiańska stała się podstawą do rozwoju plemion bardzo prężnych, ekspansywnych nawet. Pozostawione po nich dobra materialne zachwycają swym kunsztem, znamionującym bardzo wysoki stopień rozwoju cywilizacyjnego. Taki zresztą potwierdza nader skomplikowany system wierzeń.

Jednocześnie nie można odmówić racji tym, co uważają, iż na tle innych pogańskich systemów religijnych Europy, religia Słowian jest jedną z najsłabiej zachowanych. Próba odnalezienia jej sensu dokonała się dopiero w efekcie zderzenia kultury słowiańskiej z chrześcijańską. Per analogiam można tę sytuację uznać za podobną do sytuacji starożytnych, gdy sprzeczne z postawą Ojców Kościoła poglądy „heretyków” ujrzały szersze światło dzięki cytowaniu ich (w celu zwalczania) przez teologów.

Stopniowy proces wypierania pierwotnych wierzeń w kontekście chrystianizacji został zapoczątkowany w wieku VI, ostatecznie zaś zakończył się wraz z podbojem Połabian przez Niemców (XIII wiek). O prężności omawianej religii może jednak świadczyć fakt, iż na poziomie wierzeń prywatnych wyznawano ją jeszcze w XV-XVI wieku ${ }^{38}$. Pewne relikty religii pogańskiej przetrwały $\mathrm{w}$ folklorze do dziś, choć forma i skala tego zachowania budzą liczne wątpliwości, a oparte na nowoczesnych metodach badań religioznawczych wnioski rzadko uzyskują powszechne uznanie.

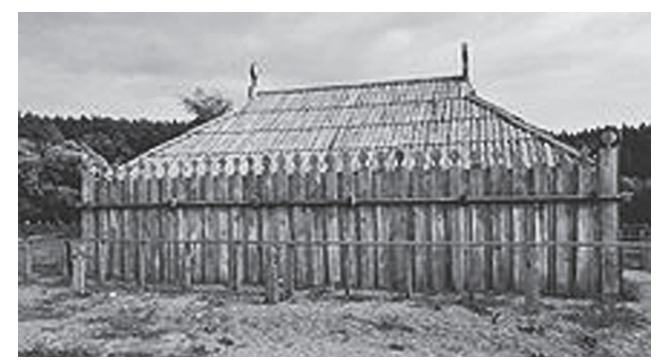

Zrekonstruowany budynek świątynny w skansenie archeologicznym Gross Raden. Wikipedia [strona niemiecka] (dostęp)

\footnotetext{
36 Zwracając uwagę na proces mentalny.

37 Por. H. Łowmiański, Religia Słowian i jej upadek, Warszawa 1979, s. 398.

38 Wydaje się zatem słuszny pogląd świeckich religioznawców, iż „Słowianie stosunkowo długo przetrwali w pogaństwie” (K. Gąssowski, art.. cyt., s. 574), aczkolwiek nie należy zapominać, iż w późniejszych wiekach była to religia bardzo zmarginalizowana.
}

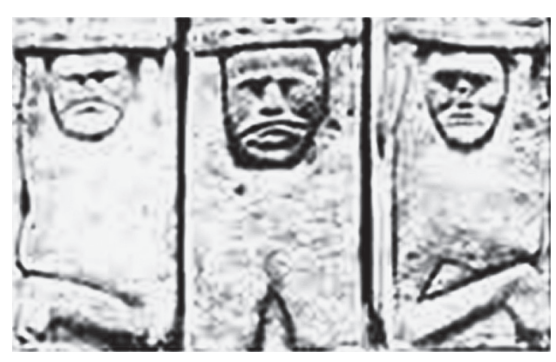

Przypuszczalne wyobrażenie Welesa - Trzygtowa $w$ dolnej partii tzw. Światowida ze Zbrucza Wikipedia, [strona niemiecka] (dostęp)

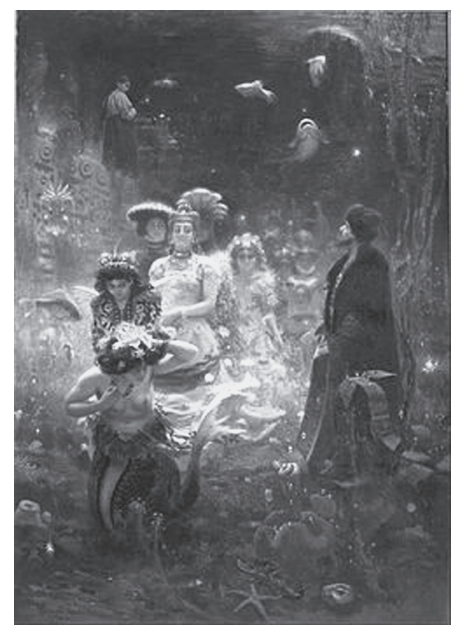

Dla wielu słowiańskich artystów inspiracją byt ich własny folklor. $\mathrm{Na}$ ilustracji obraz Sadko w podwodnym królestwie Ilji Riepina, Wikipedia [strona rosyjska] (dostęp)

\section{II}

„Pierwszych wiadomości o bogach wschodniosłowiańskich dostarczają traktaty rusko - greckie wieku X, odwołując się do nadprzyrodzonych gwarantów przysięgi składanej na dotrzymanie zawieranych układów. Pierwszy zachowany traktat Olega z roku 911 nie wspomniał o bogach odnotował natomiast, że Ruś potwierdziła umowę „klnąc się na oręż swój ”, czyli użyła środka magicznego ".

Religia Słowian wczesnośredniowiecznych była kultem uosobionej przyrody, kultem ożywionych ciał niebieskich i zjawisk atmosferycznych przedstawianych niejednokrotnie pod postacią ludzka. W. Szafrański, reprezentant dawnej szkoły slawistów uważa nawet, iż była to religia personifikująca i diwinizująca te siły natury, w czym dopatrywał się dostrzegalnych pozostałości totemizmu ${ }^{39}$. Jak się wydaje, określenie personifikacja jest chyba zbyt zawężające w tym przypadku, albowiem nie możemy dostrzec w systemie wierzeń słowiańskich odniesień do osoby par excellence. Diwinizacja zaś określa relacje między „totemem" a człowiekiem bardziej jednoznacznie. Diwinizacja ta towarzyszyła procesowi animizacji jako wyjściowemu dla określenia jakości wierzeń ${ }^{40}$.

\footnotetext{
39 Por. W. Szafrański, Religia Słowian w: Zarys dziejów religii, (praca zbiorowa pod red. Z. Poniatowskiego, Warszawa 1964, s. 477.

40 Tamże, s. 478.
} 
Obok tradycyjnego kultu ognia rozwijał się dawny kult solarny ognia niebieskiego, słońca i prastary kult płodnej Matki - Ziemi oraz kult drzewa gajów i wód. Wymienić również trzeba oddawanie całej masie drobnych duszków, opiekunów gospodarstwa domowego pomagających lub szkodzących człowiekowi, których przychylność usiłowano zjednać pozostawiając im resztki jedzenia po spożytym posiłku. Do podobnych kategorii duchów zaliczyć należy podziomki, krasnoludki, latawice, boginki, wodniki, a także demona leśnego Borutę.

„Według Prokopa z Cezarei Słowianie składają bóstwu w ofierze byki i inne zwierzęta. Saksończyk Gramatyk wspomina o ofiarach $\mathrm{z}$ bydła. Helmold i Ibn Fadlan informują, że Słowianie wschodni i zachodni zabijają bogom w ofierze woły i owce"s1.

Jak w wielu wierzeniach, podobnie u Słowian ofiary takie odgrywały znaczną rolę. Były to raczej nieskomplikowane w swym przebiegu akty ofiarnicze dokonywane bezpośrednio pod otwartym niebem, sub Jove. W pierwszym tysiącleciu po narodzeniu Chrystusa, pojawiają się jednak świątynie, drewniane budowle, niewiele różniące się od prostych zabudowań mieszkalnych. Zakreślały one ograniczone przestrzenie stanowiące sacrum ściśle oddzielone od profanum. Świątynie takie spotykamy zarówno u Słowian połabskich, jak i na Rusi. Wydaje się, iż były one zróżnicowane pod względem znaczenia, skoro najwięcej danych zachowało się na temat świątyń lutyckich; bardzo popularne też były świątynie w Jomsborgu (Rugia) oraz na Pomorzu (Szczecin i Wolin). Tworzyły one swoiste centra, gdzie zapewne nie tylko składano ofiary i się modlono, lecz także przeprowadzono narady wojenne czy dokonywano obrad miejscowych władz ${ }^{42}$. Zgodnie ze źródłami pisanymi, kapłani zostawali zatwierdzani bądź wyznaczani przez miejscową Wielką Radę, co stanowiło obowiązujące wszystkich, acz niepisane prawo $^{43}$.

Pobożność wspomagały ikonograficzne prezentacje bogów, niekiedy znacznej, trzymetrowej wysokości, sporządzane najczęściej z drewna, rzadziej zaś z kamienia. W świątyniach używano zapewne „bóstw kieszonkowych”, zminiaturyzowanych przedstawień, wykonanych niekiedy ze złota lub srebra. Posągi bóstw brały udział w bitwach, swą

Zarys dziejów religii (praca zbiorowa pod red. Z. Poniatowskiego), Warszawa 1964, s. 477 - 491 monumentalnością potwierdzając moc walczącej drużyny i próbując zdeprymować przeciwnika. Ich podobizny zdobiły też tarcze czy wojennej sztandary $y^{44}$.

Podobne odniesienia do mocy człowieka odnajdziemy w „świętojańskiej nocy Kupały” i nawiązujących do niej orgiastycznych, wspomnianych już uczt ${ }^{45}$.

\footnotetext{
41 D. Olszewski, Dzieje chrześcijaństwa w zarysie, Katowice 1982, s. 461.

42 Wolin uznać można za ważne takie centrum, skoro mogło się ono stać punktem wyjścia do hipotetycznego zaistnienia chrześcijańskiej diecezji wolińskiej.

43 Die slavische..

44 Tamże. Zapewne największą moc deprymującą miały bóstwa obdarzone więcej niż czterema głowami...

45 Tamże.
}

Z uwagi na skąpy zakres materiału źródłowego, wiele kwestii związanych z praktykami religijnymi stoi na pograniczu hipotezy lub jest takową. Jednocześnie, mimo braku „czysto słowiańskiego” mitu kosmogonicznego, znaczną rolę odgrywają archeologiczne, w miarę liczne pozostałości cmentarzy, gdzie w sposobie pochówków możemy odnaleźć stosunkowo silną obecność idei eschatologicznej. Słusznie zauważa J. Keller: „Wśród źródeł archeologicznych dominują materiały sepulkralne pochodzące $\mathrm{z}$ licznych cmentarzysk, rzadziej natomiast występują obiekty związane z magią i praktykami czarodziejskimi. Do wyjątków należą wyobrażenia figuralne istot nadprzyrodzonych i miejsca kultu" ${ }^{\prime 6}$. Sytuację taką komentuje też znany badacz systemów religijnych, Mircea Eliade, który łączy eschatologię z kosmogonią. Dla ludów prymitywnych - mówi on, - koniec świata jest tym miejscem, gdzie się realizuje przyszłość w sposób mniej lub bardziej określony. Opowiadanie o końcu świata i zniweczeniu ludzkości wskazuje też na jednostki, które mogą zostać ocalone ${ }^{47}$. W tym bowiem, co minęło zawiera się przyszłośćc ${ }^{4}$...

Dodajmy, iż eschatologia nie jest traktatem pozbawionym nadziei, a jej jednostkowa konkretyzacji w postaci nieprzekazywalnego ze swej natury doświadczenia śmierci staje się swoistym resumé jakości wierzeń.

Słowianie odwoływali się często do wyobrażenia ludzkiego ciała jako domu, gdzie mieszkała dusza. Śmierć zatem była opuszczeniem go przez duszę już to przez okno bądź drzwi, już to przez dziurę $w$ ścianie. By jednak zabezpieczyć otoczenie przed ewentualnym niezupełnym opuszczeniem ciała przez duszę, (pojmowaną nieco odmiennie, niż w chrześcijaństwie), co mogło uczynić z niej wampira, do IX post Christum wieku stosowano palenie zwłok, później jednak wyłącznie je grzebano. Wiara w wampiry i ludzkie demony była jednak nadal bardzo żywa, stanowiąc charakterystyczne proprium omawianych wierzen ${ }^{49}$.

Zetknięcie tak „prymitywnej” eschatologii pogańskiej z chrześcijańską nie okazało się jednak dla niej zgubne. Jak uważa H. Łowmiański było wręcz wprost przeciwnie. Pod pewnymi względami wbrew swym założeniom chrześcijaństwo podsycało tradycje pogańskie, zwłaszcza w kontekście kultu zmarłych, głosząc własną koncepcję eschatologiczną, a także wiarę $\mathrm{w}$ demony, które ono degradowało do roli mocy nieczystych nie przecząc ich istnieniu ${ }^{50}$.

Ważnym elementem religii są obrzędy związane ze śmiercią i pochówkiem. Wierzono $\mathrm{w}$ istnienie świata pozagrobowego. Jednak „pierwotne wierzenia ludów przedpiśmiennych odbiegały całkowicie od chrześcijańskich wyobrażeń o życiu pozagrobowym. Wiara w nieśmiertelność duszy była obca tym ludom, niemniej widziano w niej jedynie „motor” ludzkiego życia. Przyznawano jej trwanie po śmierci fizycznej w sposób duchowy. Taka jakość istnienia nie uniemożliwiała duszy ujawnienia się w postaci widzialnej. W grobie pozostawała jednak w bardzo ścisłej łączno-

\footnotetext{
46 J. Keller, Zarys dziejów religii, Warszawa 1988, s. 443.

47 Por. M. Eliade, Aspects du mythe, Paris 1966, s. 71.

48 Tamże.

49 Die slawische...

50 Por. H. Łowmiański, dz. cyt., s. 398.
} 
ści z ciałem. (...) „Toteż i kult dusz odbywa się głównie przy grobach"51 - konkluduje autor.

U Słowian wschodnich rozwinął się zwyczaj budowania niewielkich domków nad miejscami pochówku. Często wraz ze zmarłym mężczyzną grzebano uśmiercaną po jego zgonie żonę lub zastępującą ją niewolnicę. Elementami ceremonii pogrzebowej były igrzyska na cześć zmarłego (tryzna) i stypa (strawa). Zmarłemu oddawano cześć również w rok po śmierci, gdy odbywano na kurhanie ucztę, która, zwłaszcza na Białorusi wiązała się $\mathrm{z}$ wywoływaniem duchów przodków ${ }^{52}$.

Tuż przed rozpoczęciem procesu chrystianizacji Słowian rozpoczęło się stosowanie obrządku szkieletowego (chowanie zmarłych w ziemi). Zmianę zwyczaju grzebalnego uznaje się za skutek oddziaływania kultury awarskiej ${ }^{53}$. W tego rodzaju pochówkach zauważono układanie zmarłych w pozycji mocno podkurczonej, a odkrycia w okolicach Biskupina dowodzą, że zmarłych podczas pochówku krępowano sznurem, co miało im zapewnić łatwiejsze odrodzenie się w przyszłości dzięki utrzymaniu pozycji embrionalnej.

W kontekście eschatologii uwydatnia się koncepcja antropologiczna Słowian. Koncepcja ta widzi człowieka jako składnik przyrody, do istoty którego należy zarówno moc twórcza, jak i destrukcyjna. Powiązana z tą koncepcją była też wizja pośmiertnej nagrody i kary. Dla Słowian nie istniała pozagrobowa kara za grzechy (szczególnie dziedziczonym po kimś) i nagroda za dobre uczynki w sensie $\mathrm{w}$ takim, jak to przyjęto w chrześcijaństwie. Znaczenie miał natomiast bilans uczynków dobrych i złych. Za bilans dodatni oczekiwał los dobry, za ujemny odwrotnie.

Wyobrażenia zaś kary czy nagrody uznać można za bardzo plastyczne i przekonujące. Nagrodą za dobro miała być chwała i wieczna pamięć, karą zaś pełzanie w zaświatach niczym robak. Za pewne czyny (niekoniecznie własne) można też było zostać ponownie zesłanym na ziemię, by tam pod postacią zjaw, istot na wpół demonicznych lub zwierząt odkupić winy lub ujawnić prawdą odnośnie do jakiegoś tragicznego wydarzenia. Takim wydarzeniem mogło być zabójstwo, którego ofiara pod postacią widma wskazuje na sprawcę Wierzenia te znalazły swe odbicie w tzw. obrzędzie Dziadów.

\section{III}

Habent sua fata religiae realizujące się w określonym ciągu czasowym, aczkolwiek jakości tego rozwoju w przypadku wierzeń słowiańskich nie sposób ustalić. Za pewnik wszak uznać można, iż w związku z kształtowaniem się or-

\footnotetext{
51 J. Keller, Zarys dziejów religii, Warszawa 1988, s. 33. Badania sygnowane przez Eklezję Rzymskokatolicką w minionej dobie określają takie stanowisko „wiarą w żywego zmarłego" lub „żywego trupa”. Por. W. Antoniewicz, Religia dawnych Słowian w: Religie świata (praca zbiorowa pod red. Ks. Eugeniusza Dąbrwskiego), Warszawa 1957, s. 322.

52 Literackim echem mogą być Dziady A. Mickiewicza.

53 Awarowie - lud koczowniczy osiadły na terenie współczesnych Węgier, gdzie nie prowadzili jednak osiadłego trybu życia, przemieszczając się po swoim państwie wraz ze stadami, które stanowiły znaczny majątek.
}

ganizacji państwowych zaistniała konieczność przebudowy systemu wierzeń religijnych w kierunku zespolenia feudałów, podporządkowując im jednocześnie ludność zależną.

Próby takiej przebudowy religii pogańskiej w kierunku sprawniejszej obsługi potrzeb ustroju feudalnego dają się zaobserwować w działalności Włodzimierza Kijowskiego, wprowadzającego kult bóstw państwowych jako refleks koncentracji władzy świeckiej. Także w dorzeczu Odry i Wisły następuje rozbudowa wokół centralnego bóstwa hierarchii kolegium kapłańskiego sprawującego władzę teokratyczną. Jednakże dopiero chrystianizacja społeczeństw słowiańskich od schyłku VII do XII wieku zaspokoiła w pełni potrzeby państw wczesnofeudalnych w zakresie nowej, bardziej koherentnej ze strukturą społeczeństwa i wyższą jakościowo formą organizacji politycznej ideologii.

Jednakże mimo przyjęcia chrześcijaństwa wierzenia i obrzędy pogańskie przetrwały przez długie wieki. $\mathrm{O}$ „kurczowym” trzymaniu się nadal praktyk pogańskich świadczą choćby zwoływane $\mathrm{w}$ tej sprawie synody biskupie w krajach o rozwiniętej kulturze chrześcijańskiej $\mathrm{i}$ bulle papieskie, $\mathrm{z}$ których jedna dotyczy trzynastowiecznej diecezji krakowskiej. Taki stan rzeczy potwierdzają też wystąpienia kaznodziejów w XIV i XV wieku oraz opinie kronikarzy. Relikty dawnych systemów wierzeniowych przetrwały do dzisiaj w folklorze, a niejeden zwyczaj wyprowadza swój rodowód $\mathrm{z}$ dawnych praktyk obrzędowych, z guseł i zabobonów sięgających nawet starszej epoki kamienia.

Jednakże kres „oficjalnej” religii Słowian nastąpił u poszczególnych schrystianizowanych plemion dość radykalnie, co przejawiało się $\mathrm{w}$ zniszczeniu miejsc kultu i przetworzeniu jego form. Ostatnim ośrodkiem pogaństwa Słowian była świątynia w Arkonie, zniszczona w roku 1168 przez Duńczyków. Thietmar z Merseburga opisał ją około 1018 r. w sposób następujący: „Jest w kraju Redaró $w^{54}$ pewien gród o trójkątnym kształcie i trzech bramach doń wiodących, zwany Radogoszcz, który otacza zewsząd wielka puszcza, ręką tubylców nie tknięta i jak świętość czczona. Dwie bramy tego grodu stoją otworem dla wszystkich wchodzących, trzecia od strony wschodniej jest najmniejsza i wychodzi na ścieżkę, która prowadzi do położonego obok i strasznie wyglądającego jeziora. $\mathrm{W}$ grodzie znajduje się tylko jedna świątynia, zbudowana misternie z drzewa i spoczywająca na fundamencie z rogów dzikich zwierząt. Jej ściany zewnętrzne zdobią różne wizerunki bogów i bogin - jak można zauważyć, patrząc z bliska - w przedziwny rzeźbione sposób, wewnątrz zaś stoją bogowie zrobieni ludzką ręką w straszliwych hełmach i pancerzach, każdy z wyrytym u spodu imieniem. Pierwszy spośród nich nazywa się Swarożyc i szczególnej doznaje czci u wszystkich pogan. Znajdują się tam również sztandary, których nigdzie stąd nie zabierają, chyba że są potrzebne na wyprawę wojenną i wówczas niosą je piesi wojownicy. Do strzeżenia tego wszystkiego z nale-

\footnotetext{
54 Redarowie - średniowieczne plemię słowiańskie z grupy plemion lechickich, należące do Związku Wieleckiego. Głównym ośrodkiem był Radogoszcz, między innymi miejsce kultu boga Swarożyca.
} 
żytą pieczołowitością ustanowili tubylcy osobnych kapłanów" 55 .

Grupa Słowian wschodnich po przyjęciu chrztu przez długie stulecia zachowała jednak wiarę w duchy zmarłych i demony oraz w skuteczność ich interwencji w sprawy ziemskie. Ludność ta nie straciła zaufania również do środków magicznych i nie zapomniała sposobów ich użycia. Nic dziwnego, wszak także przez system wierzeń słowiańskich ujawniał się homo religiosus, rozumiejący, iż obecna sytuacja człowieka jest rezultatem wszystkich wcześniejszych przejawów i wydarzeń. Człowiek taki tworzy mity, by odsłaniały mu ich sens, by umiał rozpoznać, z jakiego

55 J. Keller, dz. cyt., s 456. powodu i w jakim celu znajduje się $\mathrm{w}$ takim, a nie innym splocie zjawisk ${ }^{56}$.

Nie powinno zatem dziwić, iż kulturowe dziedzictwo Prasłowian przekazane w tradycji ustnej - w opowieściach mitycznych, w baśniach, podaniach i legendach, w niezwykłych skojarzeniach poetyckich - oddziałuje do dziś na przeżycia i doznania człowieka. W obecnym czasie bezpośrednio do wierzeń tych i mitologii odwołują się prawnie zarejestrowane w Polsce związki wyznaniowe, takie jak Rodzimy Kościół Polski czy Zrzeszenie Wiary Rodzimej.

56 Por. M. Eliade, dz. cyt., s. 115.

\section{Bibliografia}

Kronika Thietmara. Tłumaczenie z języka łacińskiego, wstęp i przypisy Marian Zygmunt Jedlicki, Kraków 2005.

Bruckner A., Mitologia słowiańska i polska, Warszawa 1980.

Eliade M., Aspects du mythe, Paris 1966.

Gieysztor A., Mitologia Słowian, Warszawa 1980.

Janion M., Niesamowita Słowiańszczyzna, Kraków 2007.

Keller J., Zarys dziejów religii, Warszawa 1988.

Kostrzewski J., Prasłowiańszczyzna, Warszawa 1935.

Leciejewicz L. [red.], Mały słownik kultury dawnych Słowian, Warszawa 1972.

Łowmiański H., Religia Słowian i jej upadek, Warszawa.

Maszyński K., Kultura ludowa Słowian, t. I. Kraków 1934.

Olszewski D., Dzieje chrześcijaństwa w zarysie, Katowice 1982.
Strzelczyk J,, Mity, podania i wierzenia dawnych Stowian, Poznań 1998.

Szyjewski A., Religia Słowian, Kraków 2003.

Urbańczyk S., Dawni Słowianie - wiara i kult, Wrocław 1991.

Tenże, Religia pogańskich Słowian, Kraków 1947.

Vaňa Z., Świat dawnych Słowian, Warszawa 1985.

Antoniewicz W., Religia dawnych Słowian, w: Religie świata (red. Ks. Eugeniusza Dąbrowskiego), Warszawa 1957, s. 319 - 399.

Gąssowski J., Kult religijny [w:] Mały słownik kultury dawnych Słowian (pod red. L. Leciejewicza), Warszawa 1972, s. 574 - 587. Strzelczyk J., Słowianie, Encyklopedia Katolicka 18, 397 - 399.

Szafrański W., Religia Słowian, w: Zarys dziejów religii (praca zbiorowa pod red. Z. Poniatowskiego), Warszawa 1964, s. 477-491. 